\title{
CITED2 is expressed in human adrenocortical cells and regulated by basic fibroblast growth factor
}

\author{
Matthias Haase, Matthias Schott, Stefan R Bornstein ${ }^{1}$, Ludwik K Malendowicz ${ }^{2}$, Werner A Scherbaum \\ and Holger S Willenberg
}

Department of Endocrinology, Diabetes and Rheumatology, University Hospital Duesseldorf, Moorenstr. 5, D-40225 Duesseldorf, Germany

${ }^{1}$ University of Technology Dresden, University Clinic III, Dresden, Germany

${ }^{2}$ School of Medicine, Department of Histology and Embryology, Poznan, Poland

(Requests for offprints should be addressed to H S Willenberg; Email: holger.willenberg@uni-duesseldorf.de)

\begin{abstract}
CITED2 gene deletion in mice leads to adrenal agenesis. Therefore, we analyzed CITED2, a CBP/p300 interacting transactivator with transforming activity, in the human adrenal gland. In this study, we examined CITED2 expression in human embryonic and adult adrenal glands as well as adrenocortical carcinomas. As ACTH and basic fibroblast growth factor (bFGF) are connected to the physiology and growth of adrenocortical cells we studied the regulation of CITED2 by these factors in the NCI-H295R adrenocortical carcinoma cell line. We found CITED2 expression in the adult adrenal cortex as well in adrenocortical carcinomas. At an early stage of human adrenal organogenesis CITED2 could be located to the definitive zone of the developing adrenal
\end{abstract}

gland using immunohistochemistry. In NCI-H295R cells, stimulation by bFGF led to a dose-dependent increase in CITED2 promotor activity, mRNA and protein expression while ACTH had no significant effect. The stimulatory effect of bFGF could be reduced by blocking mitogen-activated protein kinase activity using the MAPkinase kinase (MEK1)inhibitor PD98059. CITED2 is expressed in embryonic and adult human adrenal glands as well as in adrenocortical cancer. It is connected to the signaling cascades of bFGF and its expression is modulated by mitogen-activated protein kinases. This suggests a novel role for CITED2 in human adrenal growth and possibly in adrenal tumorigenesis.

Journal of Endocrinology (2007) 192, 459-465

\section{Introduction}

CITED2 (CBP/p300 interacting transactivator with ED-rich tail 2) is a widely expressed transcriptional co-regulator of the cAMP response element binding protein (CREB) binding protein (CBP) and p300 (Bhattacharya et al. 1999). CITED2 expression leads to the modulation of different CBP or p300 dependent pathways including the co-activation of transcription factor AP2 by synergistic binding to CBP/p300 (Bamforth et al. 2001, Braganca et al. 2003) or the inhibiton of hypoxia inducible factor- 1 by competitive binding to $\mathrm{CBP} / \mathrm{p} 300$ (Bhattacharya et al. 1999, Freedman et al. 2003). CITED2 overexpression has been associated with oncogenic transformation and enhanced proliferation in different cell types (Sun et al. 1998, Kranc et al. 2003, Tien et al. 2004).

Mice lacking CITED2 exhibit a phenotype of cardiovascular malformations, neural crest defects, exencephaly and adrenal agenesis (Bamforth et al. 2001). Therefore, CITED2 is assumed to play a fundamental role in adrenal organogenesis, adrenal tissue growth and/or adrenal differentiation.

The human adrenal cortex arises from a combined adrenal and gonadal precursor at 4 weeks of gestation as a condensation of coelomic cells between the dorsal mesentery

and the urogenital ridge (Mesiano \& Jaffe 1997). From this site cells are believed to migrate in two waves to the cranial pole of the mesonephros forming the adrenal primordium. First, they present as a homogenous cell aggregation that gives rise to the fetal and definitive zones later. The fetal zone expresses 17- $\alpha$-hydroxylase (CYP17; Hanley et al. 1993, Mesiano et al. 1993, Narasaka et al. 2001), a key enzyme of steroid synthesis, and produces mainly dehydroepiandrosterone-sulfate. After birth, the fetal zone degenerates within the first years of life. The definitive zone lacks expression of CYP17 (Hanley et al. 1993, Mesiano et al. 1993, Narasaka et al. 2001) and it is believed that the fetal zone as well as parts of the adult adrenal zones derive from precursors of the definitive zone (Mesiano \& Jaffe 1997, Keegan \& Hammer 2002, Muench et al. 2003). Development of the adrenal medulla is initiated by neural crest-derived chromaffin cells traveling to the primordial complex of adrenocortical cells (Keegan \& Hammer 2002).

On one hand it has been speculated that adrenal agenesis observed in CITED2 $2^{-/-}$mice could be an indirect result of defects in tissues interacting with adrenocortical cells, such as the adrenal medulla. On the other hand CITED2 could be essential for the function of adrenocortical cells themselves. 
However, there is no data about CITED2 in the human adrenal gland. Therefore, in this study we focussed on the role of CITED2 in the adrenal cortex. First, we examined the expression of CITED2 during early organogenesis, in adult adrenal glands as well as in adrenocortical carcinomas. Secondly, we analyzed if CITED2 is under control of factors that are relevant for adrenal function. Since corticotropin (ACTH) is a key regulator of adrenal physiology and basic fibroblast growth factor (bFGF) has been implicated in the control of adrenocortical growth (Mesiano et al. 1991, Basile \& Holzwarth 1993, Ho \& Vinson 1997, Feige et al. 1998, Boulle et al. 2000) we hypothesized that CITED2 may be a downstream effector of these factors. Therefore, we applied NCI-H295R cells to study the regulation of CITED2 by ACTH and bFGF in adrenocortical cells.

\section{Materials and Methods}

\section{Tissues}

Four embryonic adrenal glands from two embryos at 8 weeks of gestation were obtained from an earlier study that has been approved by the Ethical Committee of the Medical School of Poznan, Poland (Ehrhart-Bornstein et al. 1997). Histological analysis was applied to determine the age of gestation. Normal adult adrenal glands $(n=4)$ were obtained from four patients who had undergone nephrectomy for renal cancer. Examination of the adrenal glands did not reveal infiltration by the renal tumor or metastases. The cancer species $(n=4)$ were obtained from tumor resection from four patients with diagnosis of adrenocortical carcinoma. All tissues were fixed in formalin and subsequently embedded in paraffin.

\section{Immunohistochemistry}

The paraffin-embedded specimen of adrenal tissues were characterized immunohistochemically using antibodies to $17-\alpha$-hydroxylase (courtesy of Prof. Waterman, Vanderbilt University School of Medicine, Nashville, TN, USA) for adrenocortical cells and to chromogranin A (clone DAK-A3, DakoCytomation, Hamburg, Germany) for chromaffin cells as previously described (Ehrhart-Bornstein et al. 1997). For CITED2 staining, sections were deparaffinized in xylene, washed in ethanol $100 \%$ and hydrated in a descending ethanol row. Then sections were processed for $4 \mathrm{~min}$ by microwave irradiation in an antigen retrieval solution (DakoCytomation). Subsequently, endogenous peroxidase was quenched with $3 \% \mathrm{H}_{2} \mathrm{O}_{2}$ and non-specific epitopes were blocked using serum-free blocking solution (supplied with DakoCytomation CSA Kit). The sections were incubated using monoclonal primary antibodies to CITED2 (Novus Biologicals, Littleton, CO, USA) in a dilution of 1:100 at room temperature for $1 \mathrm{~h}$ and signals were detected using the catalyzed signal amplification system (CSA,
DakoCytomation), according to the manufactor's instructions. Negative control slides were incubated without primary antibody. After each step, except after the blocking procedure, slides were washed at least three times in $0.05 \mathrm{~mol} / 1$ Tris $-\mathrm{HCl}(\mathrm{pH} 7 \cdot 6)$ containing $0.3 \mathrm{~mol} / \mathrm{l} \mathrm{NaCl}$ and $0.1 \%$ Tween 20 (TBST, DakoCytomation). Labeled

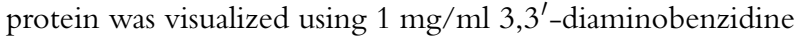
tetrahydrochloride in Tris- $\mathrm{HCl}(\mathrm{pH} 7 \cdot 6$ ) containing $0.016 \%$ $\mathrm{H}_{2} \mathrm{O}_{2}$ for 5-7 min. Nuclei were counterstained with hematoxylin (Merck) and slides were mounted in glycerol gelatine (Hollborn and Soehne, Leipzig, Germany).

\section{Cell culture and in vitro studies}

For stimulation experiments we employed the permanent adrenocortical carcinoma cell line NCI-H295R. The NCIH295R cells were cultured in RPMI 1640 + L-glutamin (Invitrogen) supplemented with $2 \%$ fetal bovine serum, insulin $(66 \mathrm{nM})$, hydrocortisone $(10 \mathrm{nM})$, apo-transferrin $(10 \mu \mathrm{g} / \mathrm{ml}), \beta$-estradiol $(10 \mathrm{nM}), \mathrm{Na}-S e l e n i t(30 \mathrm{nM})$, penicillin $(100 \mathrm{U} / \mathrm{ml})$ and streptomycin $(100 \mu \mathrm{g} / \mathrm{ml})$ at $37^{\circ} \mathrm{C}$ in a humidified atmosphere of $95 \%$ air, and $5 \% \mathrm{CO}_{2}$. Medium was changed every 3 days and cells were subcultured at confluency using Accutase (PAA Laboratories, Cölbe, Germany). Dependent on the experiments cells were plated in six-well culture plates for RNA-extraction, in 24-well culture plates for transfections or on poly-D-lysine-coated cover slips for immunofluorescence microscopy as described in the following sections.

\section{Plasmids, transfections and luciferase assays}

A firefly luciferase containing CITED2-promotor reporter plasmid was kindly provided by Bhattacharya and the sequence has been described already (Leung et al. 1999). For internal control we used pRL-TK plasmid (Promega) providing moderate expression of renilla luciferase.

NCI-H295R cells were cultured in 24-well plates at a density of 200000 cells/well and transiently co-transfected for $24 \mathrm{~h}$ using 1.5 $\mu \mathrm{l}$ FuGENE6 transfection reagent (Roche Applied Science) with $0.25 \mu \mathrm{g}$ of the CITED2 reporter construct and $0.25 \mu \mathrm{g}$ of the renilla luciferase vector pRLTK. Subsequently, cells were washed with PBS and incubated in cell culture medium for $48 \mathrm{~h}$ in the absence or presence of ACTH (100 nM, Synacthen, Ciba-Geigy, Wehr, Germany), forskolin $(10 \mu \mathrm{M}$, Sigma-Aldrich) or human bFGF $(0 \cdot 1,1$ or $10 \mathrm{ng} / \mathrm{ml}$, PromoCell, Heidelberg, Germany) either with or without PD98059 (20 $\mu \mathrm{M}$, Promega). Firefly and renilla luciferase activities were measured using Dual-Luciferase Reporter Assay System (Promega). For analysis, firefly activity was normalized to the activity of the renilla luciferase. The data is expressed as the mean \pm s.D. of three independent experiments. Statistical analysis was performed by ANOVA followed by Bonferroni's multiple comparison post test using Graph Pad Prism 4 (San Diego, CA, USA). 
Reverse transcriptase-PCR (RT-PCR)

RNAs of normal adult human adrenal cortices were obtained from BD Biosciences Clontech (Palo Alto, CA, USA) and total RNA from NCI-H295R cells was extracted using the RNeasy MiniKit (Qiagen) including a DNase I digestion step (New England Biolabs, Ipswich, MA, USA). Reverse transcription was done using Ready-To-Go t-primed first strand kit (Amersham Biosciences $\mathrm{AB}$ ) according to the manufactor's instructions. PCR analysis was carried out using a PCR Master Kit (Roche Applied Science) and the following conditions: initial denaturation of $120 \mathrm{~s}$ at $94^{\circ} \mathrm{C}$ followed by 30 three-step cycles of $30 \mathrm{~s}$ at $94{ }^{\circ} \mathrm{C}, 60 \mathrm{~s}$ at $58{ }^{\circ} \mathrm{C}$, and $120 \mathrm{~s}$ at $72{ }^{\circ} \mathrm{C}$. The whole procedure skipping reverse transcription reaction served as negative control.

Sequences of primers specific for CITED2 are given in Table 1. Amplification products were separated and visualized by agarose gel electrophoresis (3\%) and ethidium bromide staining.

\section{Semi-quantitative TaqMan PCR}

NCI-H295R cells were cultured in six-well plates at a density of 600000 cells/well and incubated in cell culture media for $8 \mathrm{~h}$ in the absence or presence of ACTH $(100 \mathrm{nM})$, forskolin $(10 \mu \mathrm{M})$, and human bFGF $(0 \cdot 1,1$ or $10 \mathrm{ng} / \mathrm{ml})$. At the end of the incubation period the medium was removed and cells were washed with PBS before the RNA extraction procedure was started. Total RNA was extracted from NCI-H295R cells using the RNeasy MiniKit (Qiagen) including a DNase I digestion step (New England Biolabs) and reverse transcribed with the random-primed first strand cDNA Kit (Roche Applied Science) according to the manufactor's instructions. For negative control reactions reverse transcription was skipped. The CITED2 specific primers and probes were selected using the software PrimerExpress (PE Applied Biosystems, Foster City, CA, USA) and are given in Table 1. Sequences of primers and probes for the endogenous control $18 \mathrm{~S}$ are also given in Table 1. Semiquantitative TaqMan PCR was carried out in 40 cycles of denaturation at $95^{\circ} \mathrm{C}$ for $15 \mathrm{~s}$ and annealing/ elongation at $58^{\circ} \mathrm{C}$ for one minute using an ABI PRISM 7700 Sequence Detector (PE Applied Biosystems). All experiments were carried out in triplicates and average $C_{\mathrm{T}}$ units were obtained as the average of the results. Relative

Table 1 Primer and probes for quantitative TaqMan analysis

Oligonucleotide Sequence $\left(5^{\prime} \rightarrow 3^{\prime}\right)$

\begin{tabular}{llll}
\cline { 2 - 3 } Name & & & \\
$18 S$ & Forward primer & CGG CTA CCA CAT CCA AGG AA \\
$18 S$ & Reverse primer & GCT GGA ATT ACC GCG GCT \\
18 S & Labeled probe & TGC TGG CAC GAG ACT TGC CCT C \\
CITED2 & Forward primer & CCA CTA CAT GCC GGA TTT GC \\
CITED2 & Reverse primer & TCT CGG AAG TGC TGG TTT GTC \\
CITED2 & Labeled probe & CCC TGC TGC AGG CCA CCA GAT
\end{tabular}

www.endocrinology-journals.org quantification of the CITED2 expression was done using the comparative $C_{\mathrm{T}}$ method in separate tubes. All data are expressed as the mean \pm s.D. of four independent experiments. Statistical analysis was performed by ANOVA followed by Bonferroni's multiple comparison post test using Graph Pad Prism 4.

\section{Immunofluorescence microscopy}

For immunofluorescence, NCI-H295R cells were seeded on poly-D-lysine (Sigma-Aldrich) coated glass cover slips and grown until they were about $70 \%$ confluent. Then cells were incubated in cell culture media for $24 \mathrm{~h}$ in the absence or presence of ACTH $(100 \mathrm{nM})$ or human bFGF $(10 \mathrm{ng} / \mathrm{ml})$ either with or without PD98059 $(20 \mu \mathrm{M})$. At the end of the incubation period, cells were fixed with methanol for $15 \mathrm{~min}$ at $-20{ }^{\circ} \mathrm{C}$, permeablized with $0 \cdot 3 \%$ Triton X-100 (SigmaAldrich) for $5 \mathrm{~min}$ and unspecific sites were blocked for $1 \mathrm{~h}$ with 5\% normal goat serum (DakoCytomation). Then cells were incubated with monoclonal anti-CITED2 antibodies (Novus Biologicals) in a dilution of $1: 100$ for $1 \mathrm{~h}$ at room temperature. The fluorescence dye conjugated secondary antibody (Alexa Fluor 488, goat anti-mouse IgG, Molecular Probes, Leiden, The Netherlands) was used in a dilution of 1:500 for $1 \mathrm{~h}$ at room temperature. Nuclei were counterstained with 4,6-diamidino-2-phenylindole (DAPI, SigmaAldrich) for $5 \mathrm{~min}$. After each step, except after the blocking procedure, cells were washed at least three times in PBS.

Finally, cover slips were mounted in Fluoromount-G (Southern Biotechnology, Birmingham, AL, USA) and preparations were examined with a Nikon Eclipse TE-300 fluorescent microscope.

\section{Results}

\section{CITED2 is expressed during early adrenal organogenesis}

Positive immunoreactivity with antibodies to CYP17 was found in the cytoplasm of cells within the inner zone of the embryonic adrenal gland at 8 weeks of gestation, marking the fetal zone (Fig. 1E). The outer zone did not show CYP17 staining and could accordingly be identified as the definitive zone.

CITED2 was expressed within the definitive zone of the adrenal gland (Fig. 1B). The expression was predominantly characterized by the labeling of small round and polygonal nuclei (Fig. 1D). In addition, we compared the expression patterns of CITED2 and chromogranin A in non-corresponding serial sections. Unlike CITED2, chromogranin A immunoreactivity was restricted to the cytoplasm of cells within the medial part of the definitive zone, representing chromaffin cells migrating from the para-aortic region to the adrenal (Fig. 1F).

\section{CITED2 is expressed in adult adrenocortical cells}

Immunohistochemistry demonstrated CITED2 protein expression in adrenocortical cells in the zonae glomerulosa 

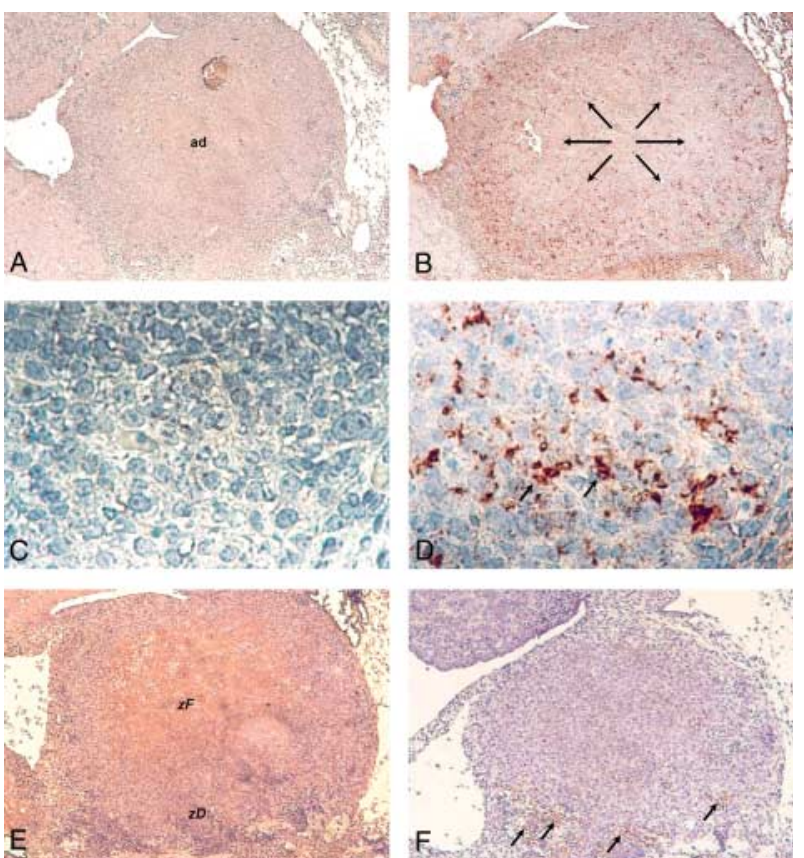

Figure 1 Representative sections of human embryonic adrenal glands at 8 weeks of gestation. Panel A: negative control without primary antibody $(\mathrm{ad}=$ adrenal, $100 \times)$. Panel B: immunostaining with antibodies to CITED2 revealed that CITED2 is located in the definitive zone (arrows, $100 \times$ ). Panel C: high magnification of a negative control demonstrates nuclear morphology in the definitive zone $(1000 \times)$. Panel D: high magnification of a representative section of the definitive zone. Predominantly, small nuclei were stained with an antibody to CITED2 (arrows, 1000×). Panel E: immunohistochemistry with an antibody to $17-\alpha$-hydroxylase identified the fetal zone $(z F)$ while the definitive zone $(z D)$ did not stain $(100 \times)$. Panel F: chromogranin A immunoreactive cells in the outside margin of the adrenal gland (arrows, 100×).

and reticularis at the cortico-medullary junction (Fig. 2B) whereas staining of cells in the zona fasciculata was somewhat weaker. In most cells, CITED2 immunoreactivity was located to the nuclei. Molecular studies using RT-PCR confirmed the expression of CITED2 on mRNA level in normal adult adrenocortical cells (Fig. 2D).

In addition, we could detect CITED2 expression in three out of four adrenocortical carcinomas using immunostaining techniques. CITED2 was distributed ubiquitously and expression was represented by a strong nuclear signal (Fig. 2C). Expression of CITED2 was also found in NCIH295R cancer cells using RT-PCR (Fig. 2D).

\section{CITED2 is regulated by bFGF}

In NCI-H295R cells, promotor activity of CITED2 was increased by bFGF in a concentration-dependent manner when assayed after an incubation period of $48 \mathrm{~h}$ (Fig. 3A). Exposure of NCI-H295R cells to bFGF at concentrations of $10 \mathrm{ng} / \mathrm{ml}$ enhanced CITED2-promotor activity significantly.
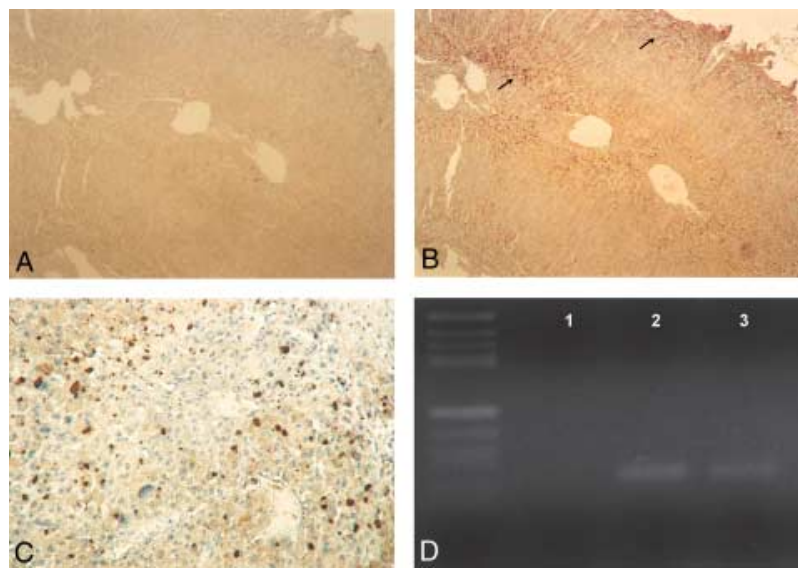

Figure 2 Representative sections of stained normal adult adrenal glands and adrenocortical carcinomas. Panel A: negative control for normal adult adrenal gland without primary antibody $(40 \times)$. Panel B: normal adult adrenal gland stained for CITED2. Arrows indicate immunoreactivity in the zonae glomerulosa and reticularis at the corticomedullary junction $(40 \times)$. Panel C: adrenocortical carcinoma stained for CITED2 showed strong nuclear expression of CITED2 $(200 \times)$. Panel D: gel of RT-PCR analysis of mRNA from normal adult human adrenal cortex (lane 2) and from NCl-H295R cells (lane 3) the $69 \mathrm{bp}$ fragments corresponded to the predicted amplification product of CITED2. As control for PCR we used RNA skipping the reverse transcription reaction (lane 1).

The stimulatory effect of bFGF could be fully blocked by co-incubation with the MEK1-inhibitor PD98059 at concenctrations of $20 \mu \mathrm{M}$. The results were confirmed using semiquantitative TaqMan PCR (Fig. 3B). Exposure of NCI-H295R cells to bFGF resulted in a marked and significant induction of CITED2-mRNA level in a concentration-dependent manner after $8 \mathrm{~h}$ of stimulation. The maximum level of induction after treatment with bFGF $(10 \mathrm{ng} / \mathrm{ml})$ varied between 15 - and 38 -fold above the unstimulated control.

Immunofluorescence technique demonstrated the induction of CITED2-protein by bFGF (Fig. 4). Exposure of NCI-H295R cells to bFGF $(10 \mathrm{ng} / \mathrm{ml})$ for $24 \mathrm{~h}$ resulted in an increased nuclear fluorescence signal. The co-inucbation of bFGF $(10 \mathrm{ng} / \mathrm{ml})$ with the MAPK-inhibitor PD98059 at concentrations of $20 \mu \mathrm{M}$ attenuated CITED2 nuclear fluorescence signal.

\section{CITED2 is regulated by forskolin}

Incubation of NCI-H295R cells for $48 \mathrm{~h}$ in the presence of forskolin $(10 \mu \mathrm{M})$ enhanced CITED2 promotor activity $1 \cdot 8-$ fold in comparison to the unstimulated control (Fig. 3C). This observation was accompanied by a $3 \cdot 5$-fold increase in CITED2-mRNA level after exposure to forskolin $(10 \mu \mathrm{M})$ for $8 \mathrm{~h}$ (Fig. 3C). In contrast to forskolin, ACTH (100 nM) did not exert a significant effect on CITED2-promotor activity, CITED2-mRNA or protein expression in NCIH295R cells (Figs 3C and 4). 


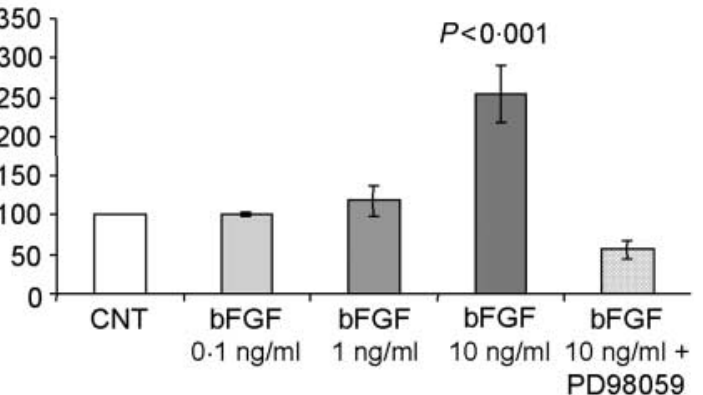

$\mathrm{B}$ $20 \mu \mathrm{M}$
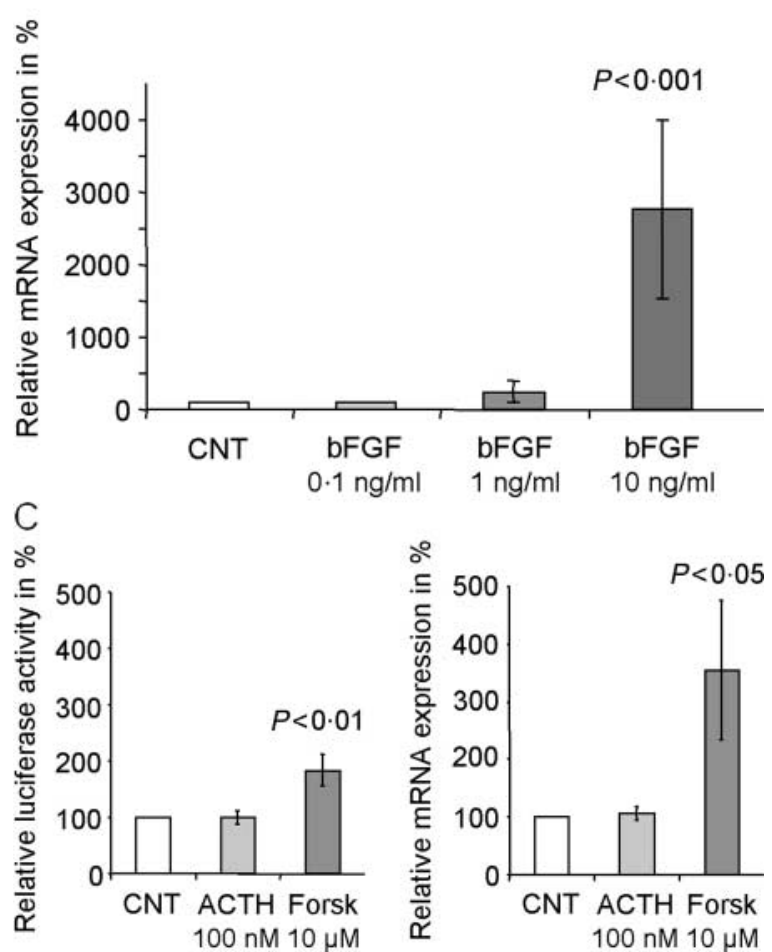

Figure 3 Regulation of CITED2-promotor activity and mRNA-level in NCl-H295R cells. Panel A: relative activity of the CITED2promotor in $\mathrm{NCl}-\mathrm{H} 295 \mathrm{R}$ cells after exposure to bFGF in different concentrations either with or without PD98059 for 48 h. Panel B: relative levels of $\mathrm{CITED} 2-\mathrm{mRNA}$ in $\mathrm{NCl}-\mathrm{H} 295 \mathrm{R}$ cells after exposure to bFGF in different concentrations for $8 \mathrm{~h}$. Panel C: effects of ACTH and forskolin (Forsk) on the CITED2-promotor activity after $48 \mathrm{~h}$ of stimulation (left panel) or on the CITED2-mRNA levels (right panel) after $8 \mathrm{~h}$ of stimulation in NCl-H295R cells. In all panels $P$-values indicate significant differences from the control (CNT).

\section{Discussion}

CITED2 has been shown to be essential for the development of the adrenal gland of the mouse (Bamforth et al. 2001). In this study, we demonstrate that CITED2 also seems to play a role in the human adrenal gland.
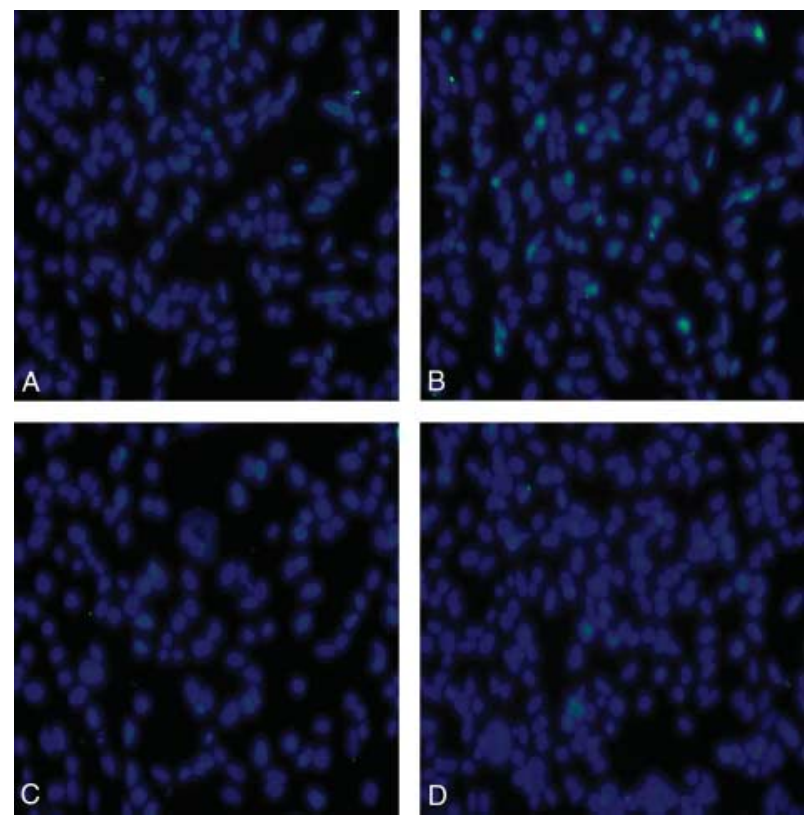

Figure 4 Immunofluorescence technique demonstrates CITED2 protein expression in $\mathrm{NCl}-\mathrm{H} 295 \mathrm{R}$ cells. Panel A: unstimulated control. Blue fluorescence dye DAPI marks nuclei. CITED2 protein is represented by a green fluorescence signal in the nuclei. Panel B: exposure of $\mathrm{NCl}-\mathrm{H} 295 \mathrm{R}$ cells for $24 \mathrm{~h}$ to $\mathrm{bFGF}(10 \mathrm{ng} / \mathrm{ml})$ increased CITED2 nuclear expression in comparison with the control. Panel C: exposure of $\mathrm{NCl}-\mathrm{H} 295 \mathrm{R}$ cells to bFGF $(10 \mathrm{ng} / \mathrm{ml})$ in combination with PD98059 $(20 \mu \mathrm{M})$ for $24 \mathrm{~h}$ attenuated CITED2 nuclear fluorescence signal in comparison with the stimulation with bFGF $(10 \mathrm{ng} / \mathrm{ml})$ alone. Panel D: exposure of $\mathrm{NCl}-\mathrm{H} 295 \mathrm{R}$ cells to ACTH $(100 \mathrm{nM})$ for $24 \mathrm{~h}$ did not exert an effect on CITED2-protein expression in comparison with the control.

The data provide the first evidence that CITED2 is expressed during early human adrenocortical organogenesis and that it is related to cells within the definitive zone. Though not studied by double-immunohistochemistry, the pictures obtained from the staining patterns in noncorresponding serial sections suggest that CITED2 expressing cells are cells other than chromogranin A positive cells. In concordance with these findings, the majority of normal adult adrenals also showed staining within the adrenal cortex: in the zona glomerulosa and in the zona reticularis at the corticomedullary junction. Interestingly, the definitive zone has been thought to represent a pool of proliferating and differentiating adrenocortical progenitor cells (Mesiano \& Jaffe 1997, Muench et al. 2003, Ratcliffe et al. 2003).

Injection of CITED2-overexpressing cells in nude mice leads to tumor formation (Sun et al. 1998) and complementation with CITED2 enhanced proliferation in fibroblasts (Kranc et al. 2003) as well as in hepatocytes (Tien et al. 2004). Therefore, it seems possible that CITED2 also co-activates factors that are important for the regulation of proliferation and growth in adrenocortical cells. In this context, our data suggest that adrenal agenesis observed in CITED2 $2^{-/-}$mice may develop as a result of primary dysfunction of adrenocortical precursor cells. 
In addition to our studies on the expression of CITED2 in adrenal tissues, we examined if CITED2 is controlled by factors important in the physiology of the adrenal gland. Many effects of ACTH are associated with the intracellular increase of cyclic AMP (cAMP). Here we demonstrate that forskolin, an activator of the adenylyl cyclase, increased both CITED2-promotor activity and mRNA levels.

In addition, we identified basic fibroblast growth factor as a potential candidate for CITED2 regulation since it is a potent mitogen for fetal and adult adrenocortical cells (Mesiano et al. 1991, Basile \& Holzwarth 1993, Ho \& Vinson 1997, Boulle et al. 2000) and since it is expressed in several adrenal tissues (Schweigerer et al. 1987, Westermann et al. 1990, Ho \& Vinson 1995, 1997). Our in vitro experiments demonstrated that CITED2 promotor activity, mRNA- and protein levels were increased by bFGF in the NCI-H295R cell-line. The stimulatory effects of bFGF were dependent on the activity of MAPKs, a familiy of extracellular regulated kinases that control a multidude of cellular functions such as survival, proliferation and differentiation. Consistent with our findings MAPKs have been shown to constitute one of the intracellular signaling pathways that are activated by bFGF in adrenocortical cells (Lepique et al. 2000, Lotfi et al. 2000, Mattos \& Lotfi 2005). Furthermore, the MAPKs are clearly linked to adrenal tumor formation. Therefore, CITED2 may also play a role in adrenal tumorigenesis. In this light, it is remarkable that CITED2 is also expressed in adrenocortical cancer.

In summary, our findings demonstrate that CITED2 is expressed in adrenocortical cells of the definitive zone of human embryonic adrenal glands, adult adrenal glands, and adrenal tumors. It is regulated by the cAMP pathway and by bFGF involving the MAPK-pathway. Therefore, similar to the murine model CITED2 is also relevant to human adrenal development and growth.

\section{Acknowledgements}

We would like to thank Bhattacharya and his co-workers who kindly provided the plasmid constructs. This work was supported by a grant from the Hedwig and Waldemar Hort Foundation and the Boehringer-Ingelheim Fonds to $\mathrm{M} \mathrm{H}$ and by grants from the Eberhard-Igler-Stiftung and WalterClawiter-Stiftung Duesseldorf, Goettingen, Germany to H S W and a grant of the Sander Stiftung to S R B. Part of the work has been presented at the 6th Adrenal Cortex/ Molecular Steroidogenesis Conference, Boston 2006. The authors declare that there is no conflict of interest that would prejudice the impartiality of this scientific work.

\section{References}

Bamforth SD, Braganca J, Eloranta JJ, Murdoch JN, Marques FI, Kranc KR, Farza H, Henderson DJ, Hurst HC \& Bhattacharya S 2001 Cardiac malformations, adrenal agenesis, neural crest defects and exencephaly in mice lacking Cited2, a new Tfap2 co-activator. Nature Genetics 29 469-474.
Basile DP \& Holzwarth MA 1993 Basic fibroblast growth factor may mediate proliferation in the compensatory adrenal growth response. American Journal of Physiology 265 R1253-R1261.

Bhattacharya S, Michels CL, Leung MK, Arany ZP, Kung AL \& Livingston DM 1999 Functional role of p35srj, a novel p300/CBP binding protein, during transactivation by HIF-1. Genes and Development 13 64-75.

Boulle N, Gicquel C, Logie A, Christol R, Feige JJ \& Le Bouc Y 2000 Fibroblast growth factor-2 inhibits the maturation of pro-insulin-like growth factor-II (Pro-IGF-II) and the expression of insulin-like growth factor binding protein-2 (IGFBP-2) in the human adrenocortical tumor cell line NCI-H295R. Endocrinology 141 3127-3136.

Braganca J, Eloranta JJ, Bamforth SD, Ibbitt JC, Hurst HC \& Bhattacharya S 2003 Physical and functional interactions among AP-2 transcription factors, p300/CREB-binding protein, and CITED2. Journal of Biological Chemistry 278 16021-16029.

Ehrhart-Bornstein M, Breidert M, Guadanucci P, Wozniak W, BocianSobkowska J, Malendowicz LK \& Bornstein SR 199717 alphaHydroxylase and chromogranin A in 6th week human fetal adrenals. Hormone and Metabolic Research 29 30-32.

Feige JJ, Vilgrain I, Brand C, Bailly S \& Souchelnitskiy S 1998 Fine tuning of adrenocortical functions by locally produced growth factors. Journal of Endocrinology 158 7-19.

Freedman SJ, Sun ZY, Kung AL, France DS, Wagner G \& Eck MJ 2003 Structural basis for negative regulation of hypoxia-inducible factor-1-alpha by CITED2. Nature Structural Biology 10 504-512.

Hanley NA, Rainey WE, Wilson DI, Ball SG \& Parker KL 1993 Expression profiles of SF-1, DAX1, and CYP17 in the human fetal adrenal gland: potential interactions in gene regulation. Molecular Endocrinology 15 57-68.

Ho MM \& Vinson GP 1995 Endocrine control of the distribution of basic fibroblast growth factor, insulin-like growth factor-I and transforming growth factor-beta 1 mRNAs in adult rat adrenals using non-radioactive in situ hybridization. Journal of Endocrinology 144 379-387.

Ho MM \& Vinson GP 1997 Peptide growth factors and the adrenal cortex. Microscopy Research and Technique 36 558-568.

Keegan CE \& Hammer GD 2002 Recent insights into organogenesis of the adrenal cortex. Trends in Endocrinology and Metabolism 13 200-208.

Kranc KR, Bamforth SD, Braganca J, Norbury C, van Lohuizen M \& Bhattacharya S 2003 Transcriptional coactivator Cited2 induces Bmi1 and Mel18 and controls fibroblast proliferation via Ink4a/ARF. Molecular and Cellular Biology 23 7658-7666.

Lepique AP, Forti FL, Moraes MS \& Armelin HA 2000 Signal transduction in G0/G1-arrested mouse Y1 adrenocortical cells stimulated by ACTH and FGF2. Endocrine Research 26 825-832.

Leung MK, Jones T, Michels CL, Livingston DM \& Bhattacharya S 1999 Molecular cloning and chromosomal localization of the human CITED2 gene encoding p35srj/Mrg1. Genomics 61 307-313.

Lotfi CF, Costa ET, Schwindt TT \& Armelin HA 2000 Role of ERK/MAP kinase in mitogenic interaction between ACTH and FGF2 in mouse Y1 adrenocortical tumor cells. Endocrine Research 26 873-877.

Mattos GE \& Lotfi CF 2005 Differences between the growth regulatory pathways in primary rat adrenal cells and mouse tumor cell line. Molecular and Cellular Endocrinology 245 31-42.

Mesiano S \& Jaffe RB 1997 Developmental and functional biology of the primate fetal adrenal cortex. Endocrine Reviews 18 378-403.

Mesiano S, Mellon SH, Gospodarowicz D, Di Blasio AM \& Jaffe RB 1991 Basic fibroblast growth factor expression is regulated by corticotropin in the human fetal adrenal: a model for adrenal growth regulation. PNAS $\mathbf{8 8}$ 5428-5432.

Mesiano S, Coulter CL \& Jaffe RB 1993 Localization of cytochrome P450 cholesterol side-chain cleavage, cytochrome P450 17 alpha-hydroxylase/17, 20-lyase, and 3 beta-hydroxysteroid dehydrogenase isomerase steroidogenic enzymes in human and rhesus monkey fetal adrenal glands: reappraisal of functional zonation. Journal of Clinical Endocrinology and Metabolism 77 1184-1189.

Muench MO, Ratcliffe JV, Nakanishi M, Ishimoto H \& Jaffe RB 2003 Isolation of definitive zone and chromaffin cells based upon expression of CD56 (neural cell adhesion molecule) in the human fetal adrenal gland. Journal of Clinical Endocrinology and Metabolism 88 3921-3930. 
Narasaka T, Suzuki T, Moriya T \& Sasano H 2001 Temporal and spatial distribution of corticosteroidogenic enzymes immunoreactivity in developing human adrenal. Molecular and Cellular Endocrinology 174 111-120.

Ratcliffe J, Nakanishi M \& Jaffe RB 2003 Identification of definitive and fetal zone markers in the human fetal adrenal gland reveals putative developmental genes. Journal of Clinical Endocrinology and Metabolism $\mathbf{8 8}$ 3272-3277.

Schweigerer L, Neufeld G, Friedman J, Abraham JA, Fiddes JC \&

Gospodarowicz D 1987 Basic fibroblast growth factor: production and growth stimulation in cultured adrenal cortex cells. Endocrinology 120 796-800.

Sun HB, Zhu YX, Yin T, Sledge G \& Yang YC 1998 MRG1, the product of a melanocyte-specific gene related gene, is a cytokine-inducible transcription factor with transformation activity. PNAS 95 13555-13560.
Tien ES, Davis JW \& Van den Heuvel JP 2004 Identification of the CREBbinding protein/p300-interacting protein CITED2 as a peroxisome proliferator-activated receptor alpha coregulator. Journal of Biological Chemistry 279 24053-24063.

Westermann R, Johannsen M, Unsicker K \& Grothe C 1990 Basic fibroblast growth factor (bFGF) immunoreactivity is present in chromaffin granules. Journal of Neurochemistry 55 285-292.

Received in final form 17 November 2006

Accepted 22 November 2006

Made available online as an Accepted Preprint

12 December 2006 